\title{
TEACHING METHODS USED IN SPECIAL EDUCATION: A CONTENT ANALYSIS STUDY
}

\author{
Dr. Hüseyin Uzunboylu, Near East University, Faculty of Open and Distance Education, Lefkosa, North Cyprus, \\ Turkey \\ E-mail: huseyin.uzunboylu@gmail.com \\ Dr. Deniz Özcan, Ondokuz Mayıs University, Education Faculty, Special Education Department, Samsun, \\ Turkey \\ E-mail: deniz.ozcan@omu.edu.tr
}

A R T I C L E I N F O
Review Article
Received: July, 20.2019.
Revised: August, 12.2019.
Accepted: August, 20.2019.
doi:10.5937/IJCRSEE1902099U
UDK
376.1:371.3
$050: 376.1$

Keywords: teaching method, special education, content analysis, citation analysis.

\begin{abstract}
A B S T R A C T
This study aims to reveal the situation and trends in teaching methods used in special education. Content analysis and citation analysis were used in this study as a research model. Published documents were obtained from Scopus by using the keywords 'teaching method' and 'special education' and a total number of 63 documents were obtained. The published documents were examined based on the previously determined content analysis criteria involving year of publication, name of the journals, authors, affiliations, countries, document type, subject area, keywords, language and citations. Data were analysed and provided with frequency and percentages. Results generally showed that there is an increase in the number of researches on teaching methods and special education throughout the years, most of the published documents were articles and from the areas of social sciences and psychology. All of the results were discussed with the relevant literature and recommendations for further research and practices were presented.
\end{abstract}

(C) 2019 IJCRSEE. All rights reserved.

\section{INTRODUCTION}

Today's world has been witnessing considerable changes in many fields due to the recent technological advancements. Education is one of these fields that have been notably affected by such developments. The main trend in modern education today is to adopt a student-centred approach in teaching instead of teacher-centred traditional approaches because each student is unique, and their learning styles and capacities greatly differ from each other (Ozbal and Eski, 2019).

The principle of equal opportunity in education is one of the basic priorities of democratic societies and precisely, it is not possible to provide this to students with special needs without providing special education services (Agha and ELDaou, 2018; Ball, 2012; Lynch Corresponding Author

Dr. Hüseyin Uzunboylu, Near East University, Faculty of Open and Distance Education, Lefkosa, North Cyprus, Turkey

E-mail: huseyin.uzunboylu@gmail.com

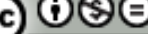

This work is licensed under a Creative Commons Attribution - NonCommercial - NoDerivs 4.0. The article is published with Open Access at www.ijcrsee.com and Baker, 2005). Individuals with special needs have different requirements and characteristics from their peers with typical development in terms of physical, social, mental and emotional development. Individuals with special needs might differ significantly from the level expected from his or her age in terms of individual characteristics and educational competence for various reasons (Baglama, Serttas and Demirok, 2017; Bateman and Bateman, 2014).

Fulcher (2015) indicated that there is a need to make legal, administrative and educational arrangements for individuals with special needs to benefit from equal education and life opportunities as individuals with normal developmental characteristics. After the implementation of 'Individuals with Disabilities Education Act' in 1975; it is aimed to ensure that every individual with special needs have the right to benefit from appropriate educational services. In addition, preventing stigmatization of individuals with special needs, evaluation without focusing on differences, preparing individualized education programs, providing a less restricted environment in education, inclusion and ensuring a legal base for these issues were also mentioned and targeted in the implementation of the act (Flanagan, 
1995). Today, every individuals with special needs have the right to receive education as their peers, and mainstreaming and inclusion practices have increased in order to include them in regular education environments to be able to spend time and receive education with their peers, feel as a part of the society and therefore, increase their self-confidence and daily living skills (Cook, Klein and Chen, 2015; Dogan and Bengisoy, 2017; Rajendran, Reddy and Reddy, 2017; Sivrikaya and Yikmis, 2016).

Furthermore, Akcamete (2015) stated that the main purpose of special education services is to provide the independent living skills necessary for individuals to continue their lives in society without being dependent on others. Individuals with special needs require additional support in learning various skills necessary for living in a society independently. These skills might involve selfcare, daily living skills, shopping, travelling and functional academic skills such as reading, writing and mathematical skills based on individuals' requirements. Acquisition of these skills is possible with designing and providing the most appropriate content, goals and content for their programmes. Accordingly, it is important to present the content with the appropriate teaching method and approach for the education of individuals with special needs (Argyropoulos, V. and Chamonikolaou, S., 2016; Friend and Bursuck, 2018; Uzunboylu, Kinik and Kanbul, 2017).

The use of correct and effective methods in learning and teaching processes is more important than increasing the student's learning. There are many methods used in learningteaching processes. What is important is that when the teacher is teaching the content, he chooses the most appropriate and appropriate method for the students' level. As well as general methods, each field has its own methods (Kurt and Yavuz, 2018).

Teaching methods in special education generally aims to gain and/or increase appropriate behaviours and prevent, decrease and/ or remove inappropriate behaviours of individuals with special needs in order to maintain their lives independently (Demirok, Meral Karabacak and Aysever, 2019). This could be achieved with applied behavioural analysis approach, which is widely used in special education. At this point, it is important to mention that there are various teaching methods used in special education in which their effectiveness are shown with many scientific research (Mitchell, 2014; Odom et al., 2005; Sue-En- glert, Tarrant and Mariage, 1992).

When choosing the right and most effective teaching method for individuals with special needs, type of the skills that will be taught, individual characteristics of the child and educational requirements, learning environments and teaching materials and accessibility of support services (Kukey, Gunes, and Genç, 2019). There are additional teaching methods for gaining various skills to individuals with special needs. Forward chaining, inverse forward chaining and whole skill teaching are some examples for these methods. Physical help, verbal cues, modelling, etc., are also used in teaching individuals with special needs (Bloh et al., 2017). Nevertheless, there are additional teaching methods used in special education involving direct instruction (Bechtolt et al., 2014; Eratay and Yeseriroglu, 2017), natural teaching (Wolery, Bailey and Sugai, 1988), computer-assisted education (Bakker, Heuvel-Panhuizen and Robitzsch, 2016; Ozdamli, 2017) and sensory-based teaching (Barton et al., 2015).

Apart from these teaching methods, errorless teaching methods are one of the most broadly used methods in special education. Errorless teaching is an approach developed based on skills and concept teaching is achieved with the positive effect of responses and exercises during teaching instead of the errors during instruction (Wolery, Bailey and Sugai, 1988). This approach emerged because it is noticed that error levels are increased when teaching individuals with special needs through traditional teaching methods. When the error level is decreased with errorless teaching methods, a positive interaction between a learner and a teacher has been established. In skills teaching based on errorless teaching methods, cues are given for the child to display target behaviours and these cues need to be provided based on a systematic plan in order to be effective. Therefore, many different methods were developed related with the use of cues. These methods involve increasing the cue, increasingly reducing the cue, simultaneous prompting, incremental cue, increased waiting time, prebehaviour cue and test, pre-behaviour cue and cue retraction and fixed waiting time (BragaKenyon et al., 2017; Sorakin and Uzunboylu, 2017; Tekin-Iftar and Kircaali-Iftar, 2013).

It is essential for individuals with special needs to use accurate, appropriate and effective teaching methods and approaches. As it can be understood, there are various teaching methods used in special education. When the literature is examined, it is seen that the 
number of studies were providing a review for prevalently used effective teaching methods in special education. Therefore, this study aims to reveal the situation and trends in teaching methods and special education. It is expected that this study would provide a guidance for researchers and teachers about which teaching methods are used in special education and which of them are more beneficial and effective.

\section{MATERIALS AND METHODS}

Content analysis and citation analysis were used in this research as a research model. Content analysis is a qualitative research method which involves the objective and systematic analysis of verbal, written or other materials (Deepaen, 2016; Tavsancil and Aslan, 2001). Citation analysis is a method of investigating the frequency, patterns, trends and graphs of citations in a group of documents (Moed, 2006). Published documents in Scopus, which is one of the most prestigious databases (Ozkan and Uzunboylu, 2017) were examined in this study. The published documents were obtained through searching keywords 'teaching method' and 'special education' in order to reveal the current situation and trends in this area.

\subsection{Data collection}

Data of the current study included the published documents on teaching methods in special education in Scopus database between the years of 1975-2017. These articles were searched by the researchers and a total number of 83 articles were obtained at the end of the data collection.

Figure 1. The teaching method and special education search page in Scopus

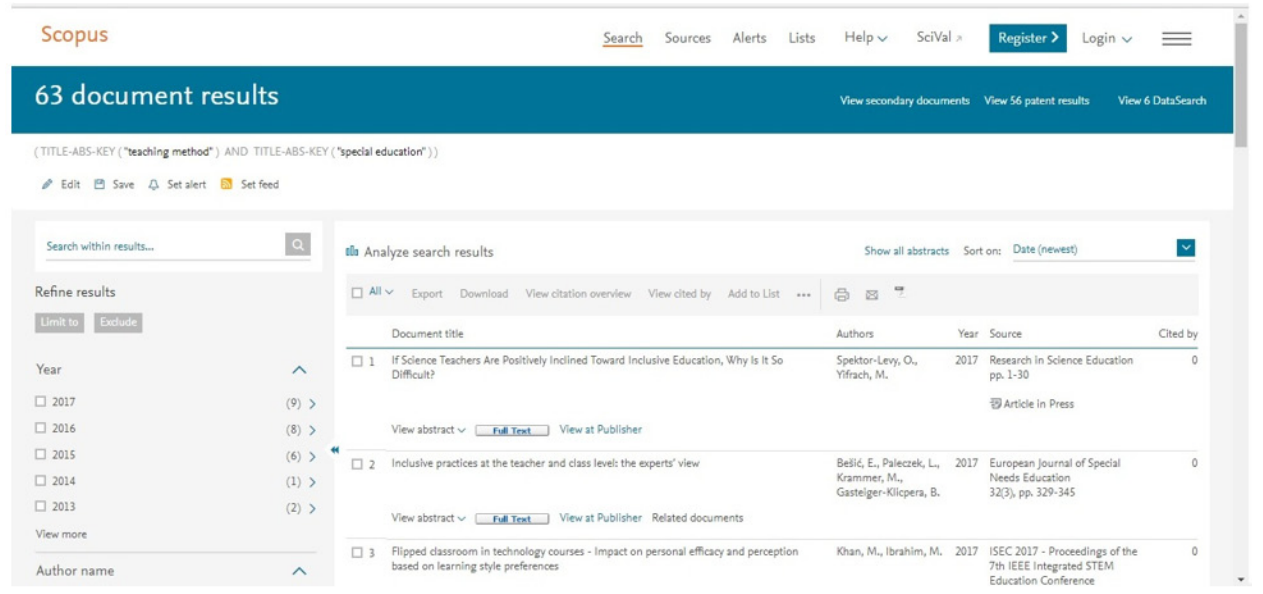

\subsection{Data analysis}

In data analysis, content analysis criteria were determined to examine the published documents in Scopus database. These criteria included year of publication, name of the journals, authors, universities, countries, document type, subject area, keywords, language and most cited documents.

\section{RESULTS}

A total number of 63 articles were examined based on the review of Scopus. Results were interpretted based on the content analysis criteria and discussed with relevant research from the literature.

\subsection{Distribution of the articles based on the year of publication}

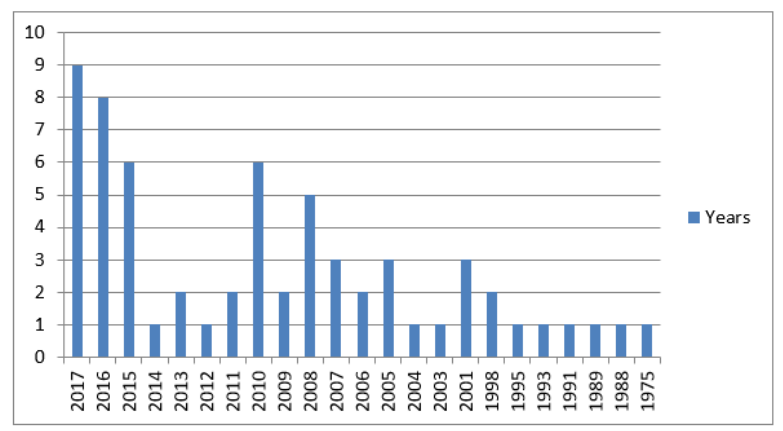

Figure 2. Distribution of the articles based on the year of publication

As it can be seen, Figure 2 shows the distribution of the articles on teaching methods used in special education based on the year of publication in Scopus database. The years between 1976. and 1988. are not included in the figure, since there were no publications 
on teaching methods and special education in these years. Results showed that there are nine articles published in 2017., eight articles in 2016. and six articles in 2015. throughout the 63 articles analysed in the study. Therefore, it can be said that there is a regular increase in the number of publications related with teaching methods used in special education.

\subsection{Distribution of the articles based on the name of the journals}

Table 1. Name of the journals in which the articles published

\begin{tabular}{lcc}
\hline \multicolumn{1}{c}{ Journal name } & $f$ & $\%$ \\
\hline $\begin{array}{l}\text { European Journal of } \\
\text { Special Needs Education }\end{array}$ & 3 & 4.76 \\
\hline $\begin{array}{l}\text { Asia Pacific Disability } \\
\text { Rehabilitation Journal }\end{array}$ & 2 & 3.17 \\
\hline $\begin{array}{l}\text { Egitim ve Bilim } \\
\text { (Education and Science) }\end{array}$ & 2 & 3.17 \\
\hline $\begin{array}{l}\text { International Journal of } \\
\text { Special Education } \\
\text { Other journals }\end{array}$ & 2 & 3.17 \\
\hline Total & 54 & 85.72 \\
\hline
\end{tabular}

Distribution of the articles based on the name of the journals is shown in Table 1. Since there was only one publication in 44 journals, they are not provided in the table and the highest four journals are shown. As it can be seen, the highest number of publication is in European Journal of Special Needs Education ( $\mathrm{f}=$ 3, 4.76\%); Asia Pacific Disability Rehabilitation Journal, Egitim ve Bilim (Education and Science) and International Journal of Special Education have two publications related with teaching methods and special education.

\subsection{Results on the authors of the articles and their affiliations}

Results regarding the authors of the articles and their affiliations were not shown as table or figure, since each author published documents once in the area and it would not be possible to be able to illustrate this in a table or figure. This result might be because the area is new and authors published on teaching methods and special education in Scopus have not specified an expertise yet. In addition, this might be also related with the fact that special education is an interdisciplinary field and authors from different disciplines might have published the articles. According to the results, Bar-Ilan University and Beit Berl Academic
College are the top two academic institutions mentioned as affiliations in the articles and the remaining affiliations were only with one frequency. These results suggested that there is no steady trend in the affiliations of authors.

\subsection{Distribution of the articles based on the countries}

Table 2. Articles and their countries

\begin{tabular}{lcc}
\hline \multicolumn{1}{c}{ Countries } & $f$ & $\%$ \\
\hline United States & 19 & 30.15 \\
\hline Israel & 8 & 12.69 \\
\hline Turkey & 5 & 7.94 \\
\hline Brazil & 3 & 4.76 \\
\hline Malaysia & 3 & 4.76 \\
\hline Taiwan & 3 & 4.76 \\
\hline Belgium & 2 & 3.17 \\
\hline Denmark & 2 & 3.17 \\
\hline Germany & 2 & 3.17 \\
\hline United Kingdom & 2 & 3.17 \\
\hline Other countries & 14 & 22.22 \\
\hline Total & 63 & 100 \\
\hline
\end{tabular}

In Table 2, distribution of the articles based on the countries of the researchers is provided and the top 10 countries were mentioned in the table and the others with one frequency were not included. There were a total number of 31 countries which have been indicated as the countries of the authors. According to Table 3, it can be seen that most articles have been published by the authors from the United States ( $f=19,30.15 \%$ ) and as the second frequent country of the authors, there were eight authors from Israel $(12.69 \%)$ and there were five authors from Turkey $(\mathrm{f}=5,7.94 \%)$. Besides, there were three authors from Brazil, Malaysia and Taiwan ( $\mathrm{f}=3,4.76 \%)$ and two authors were from Belgium, Denmark, Germany and the United Kingdom ( $f=2,3.17 \%$ ). The other remaining countries constituted the $77.78 \%$ with one publication from each country. 


\subsection{Distribution of the published documents based on the document type}

Table 3. Document types of the published documents

\begin{tabular}{lcc}
\hline \multicolumn{1}{c}{ Document type } & $f$ & $\%$ \\
\hline Article & 46 & 73.01 \\
\hline Conference paper & 9 & 14.29 \\
\hline Review & 4 & 6.35 \\
\hline Book chapter & 2 & 3.17 \\
Article in press & 1 & 1.59 \\
\hline Short survey & 1 & 1.59 \\
\hline Total & 63 & 100 \\
\hline
\end{tabular}

Table 3 shows the distribution of the published documents based on the document type. Results indicated that most of the published documents were articles ( $\mathrm{f}=46$, $73.02 \%$ ). According to this result, it can be inferred that authors prefer to publish research articles. Besides, nine of the published documents were conference papers (14.29\%), four of them were reviews $(6.35 \%)$, two of them were book chapters $(3.17 \%)$ and the remaining two published documents were article in press and short survey $(1.59 \%)$.

\subsection{Distribution of the articles based on the subject area}

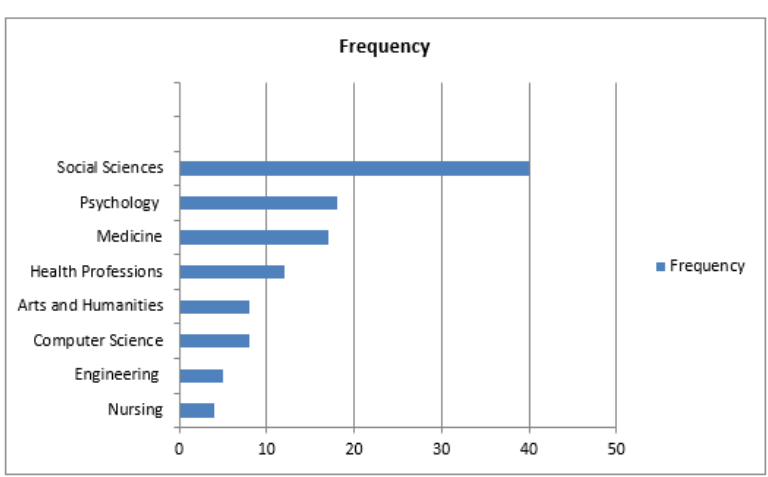

Figure 3. Frequency distribution of the articles based on the subject area

Figure 3 shows the distribution of the articles based on the subject area. As it can be seen, social sciences were the most studied subject area with 40 published documents. Results showed that there were 18 published documents from the area of psychology, 17 published documents from the area of medi- cine, 12 published documents from the area of health professions, eight published documents from the area of arts and humanities and computer Science, five published documents from the area of engineering and four published documents from the area of nursing.

\subsection{Distribution of the articles based on the keywords}

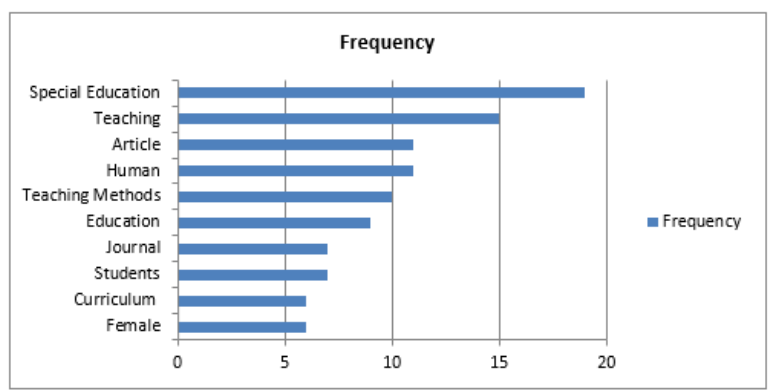

Figure 4. Keywords used in the published documents

Figure 4 shows the distribution of the articles based on the keywords mentioned in the published documents. The top $10 \mathrm{key}-$ words obtained from the published documents were included in the figure. According to the results, it can be inferred that 'special education' is the most used keyword in the published documents related with teaching methods and special education in Scopus database. This result is followed by 'teaching', 'article', 'human' and 'teaching methods'. In addition, 'education', 'journal', 'students', 'curriculum' and 'female' were the other mostly used keywords in the published documents. Therefore, it can be said that, there are various keywords used in the published documents and 'special education' as the relevant field was the most used keyword.

\subsection{Distribution of the articles based on the language}

Table 4. Language of the published documents

\begin{tabular}{lcc}
\hline \multicolumn{1}{c}{ Language } & $f$ & $\%$ \\
\hline English & 56 & 88.90 \\
\hline Portuguese & 3 & 4.76 \\
\hline French & 2 & 3.17 \\
\hline Turkish & 2 & 3.17 \\
\hline Total & 63 & 100 \\
\hline
\end{tabular}


Language of the published documents are shown in Table 4. As it can be seen, most of the published documents were written in English ( $f=56,88.90 \%)$. In addition, there

\subsection{The most cited documents on teaching methods and special education in Scopus}

Table 5. Most cited documents

\begin{tabular}{|c|c|c|c|c|c|}
\hline No. & Document title & Author(s) & Year & Source & Cited by \\
\hline 1. & $\begin{array}{l}\text { Following the child's lead when teaching } \\
\text { nouns to preschoolers with mental } \\
\text { retardation }\end{array}$ & $\begin{array}{l}\text { Yoder, P.J., } \\
\text { Kaiser, A.P., } \\
\text { Alpert, C., } \\
\text { Fischer, R. }\end{array}$ & 1993 & $\begin{array}{l}\text { Journal of Speech } \\
\text { and Hearing } \\
\text { Research, 36(1), } \\
\text { pp. 158-167. }\end{array}$ & 49 \\
\hline 2. & Inclusion and burnout in physical education & $\begin{array}{l}\text { Fejgin, N., } \\
\text { Talmor, R., } \\
\text { Erlich, I. }\end{array}$ & 2005 & $\begin{array}{l}\text { European Physical } \\
\text { Education Review } \\
11(1), \text { pp. } 29-50 \\
\end{array}$ & 25 \\
\hline 3. & $\begin{array}{l}\text { Brief report: Outcomes of a teacher training } \\
\text { program for autism spectrum disorders }\end{array}$ & $\begin{array}{l}\text { Probst, } \mathrm{P} . \text {., } \\
\text { Leppert, T. }\end{array}$ & 2008 & $\begin{array}{l}\text { Journal of Autism } \\
\text { and Developmental } \\
\text { Disorders } \\
38(9), \text { pp. } 1791- \\
1796\end{array}$ & 22 \\
\hline 4. & $\begin{array}{l}\text { Improving the comprehension of disabled } \\
\text { readers }\end{array}$ & Williams, J.P. & 1998 & $\begin{array}{l}\text { Annals of Dyslexia } \\
48, \mathrm{pp} .213-232\end{array}$ & 22 \\
\hline 5. & $\begin{array}{l}\text { Brain-(not) based education: Dangers of } \\
\text { misunderstanding and misapplication of } \\
\text { neuroscience research }\end{array}$ & $\begin{array}{l}\text { Alferink, L.A., } \\
\text { Farmer-Dougan, } \\
\text { V. }\end{array}$ & 2010 & $\begin{array}{l}\text { Exceptionality } \\
18(1), \text { pp. } 42-52\end{array}$ & 20 \\
\hline 6. & $\begin{array}{l}\text { Inclusive Schooling - Middle School } \\
\text { Teachers' Perceptions }\end{array}$ & Heiman, $\mathrm{T}$. & 2001 & $\begin{array}{l}\text { School Psychology } \\
\text { International } \\
22(4), \text { pp. } 451-462\end{array}$ & 17 \\
\hline 7. & $\begin{array}{l}\text { Creating and sustaining a special } \\
\text { education/general education partnership: A } \\
\text { story of change and uncertainty }\end{array}$ & $\begin{array}{l}\text { Trent, S.C., } \\
\text { Driver, B.L., } \\
\text { Wood, M.H., (...), } \\
\text { Martin, T.F., } \\
\text { Smith, W.G. }\end{array}$ & 2003 & $\begin{array}{l}\text { Teaching and } \\
\text { Teacher Education } \\
19(2) \text {, pp. 203-219 }\end{array}$ & 16 \\
\hline 8. & $\begin{array}{l}\text { Private school diversity in Denmark's } \\
\text { national voucher system }\end{array}$ & Rangvid, B.S. & 2008 & $\begin{array}{l}\text { Scandinavian } \\
\text { Journal of } \\
\text { Educational } \\
\text { Research } \\
\text { 52(4), pp. 331-354 }\end{array}$ & 15 \\
\hline 9. & $\begin{array}{l}\text { The efficacy of reciprocal teaching in } \\
\text { fostering the reading literacy of students } \\
\text { with intellectual disabilities }\end{array}$ & $\begin{array}{l}\text { Alfassi, M., } \\
\text { Weiss, I., } \\
\text { Lifshitz, H. }\end{array}$ & 2009 & $\begin{array}{l}\text { European Journal } \\
\text { of Special Needs } \\
\text { Education } \\
24(3), \text { pp. } 291-305\end{array}$ & 11 \\
\hline 10 & $\begin{array}{l}\text { Computer graphics applications in the } \\
\text { education process of people with learning } \\
\text { difficulties }\end{array}$ & $\begin{array}{l}\text { Vera, L., Campos, } \\
\text { R., Herrera, G., } \\
\text { Romero, C. }\end{array}$ & 2007 & $\begin{array}{l}\text { Computers and } \\
\text { Graphics } \\
\text { (Pergamon) } \\
31(4), \text { pp. } 649-658\end{array}$ & 10 \\
\hline
\end{tabular}

Table 5 shows the most cited documents on teaching methods and special education in Scopus. The top 10 most cited documents are shown in the table. As it can be seen, the most frequently-cited articles generally focused on mental retardation, inclusion, for autism spectrum disorder and learning difficulties. The article with the highest citations was published in 1993. This is probably because articles that were published earlier have a greater chance of being accessed and cited by other related studies.

\section{DISCUSSION}

This study aimed to determine the trends in the documents related with teaching methods in special education published between the years of 1975-2017. Providing a sys- were three documents written in Portuguese, two documents in French and two documents in Turkish. 
cial education and teaching methods were specifically examined in the present study.

Furthermore, results showed that European Journal of Special Needs Education was the first journal with the highest number of publications related with teaching methods and special education. In addition, Bar-Ilan University and Beit Berl Academic College are the top two academic institutions mentioned as affiliations in the articles. Results also indicated that most articles have been published by the authors from the United States. This result is similar with the results of other studies showing an increase in special education research through content analysis. For example, Gedrimas (2015) found that most of the data collected for autism research were from the United States; and Demirok, M. S., Baglama, B., and Besgul, M. (2015) also found that most of the studies on special education were conducted in America.

When the results on the document types are analysed, it is seen that most of the published documents were articles. Moreover, social sciences were found as the most studied subject area with 40 published documents. This might be because of the interdisciplinary nature of special education area and social sciences might involve psychological and educational research as well. It was also determined that that 'special education' is the most used keyword in the published documents related with teaching methods and special education in Scopus database and most of the published documents were written in English. This could be associated with the fact that English as a universal language spoken, known and understood throughout the world and is the most frequently used language in the academic literature (Crystal, 2012). Finally, citation analysis of the papers revealed that the most cited documents were from Journal of Speech and Hearing Research published in 1993. with 49 citations and this is followed by European Physical Education Review in 2005. with 25 citations and Journal of Autism and Developmental Disorders in 2008. with 22 citations.

\section{CONCLUSION AND RECOMMENDATIONS}

In conclusion, this study provided an overview of studies on teaching methods and special education published in Scopus based on certain criteria. This study introduced the studies on teaching methods and special education, and therefore, it is expected that it would provide a guidance for teachers and researchers. Following recommendations for further research and practices were presented based on the results of the present study:

- Other scientific databases might be examined in order to reveal the trends in research on teaching methods and special education.

- Further research might focus more on the teaching methods in special education especially for teachers to provide a guidance on what are the current and evidence-based teaching methods in special education.

- Different content analysis criteria such as research sample, topic, method and number of authors might be used to reveal these tendencies in the research as well.

\section{Conflict of interests}

The authors declare no conflict of interests.

\section{REFERENCES}

Agha, Z., \& ELDaou, B. (2018). The role of the special education centers in developing students' holistic wellbeing. Journal of Education and Special Education Technology, 4(1), 1-13. https://doi. org/10.18844/jeset.v4i1.4056

Argyropoulos, V., \& Chamonikolaou, S. (2016). Investigating key functions of hand movements by individuals with visual impairment: Improving instructional practices in special education through research. Contemporary Educational Researches Journal, 6(1), 2-10. https://doi. org/10.18844/cerj.v6i1.485

Akçamęte, A. G. (2015). Genel Eğitim Okullarında Özel Gereksinimi Olan Öğrenciler ve Özel Eğitim (2. Bask1). Ankara: Pegem Publishing. https://www.pegem.net/kitabevi/118696Genel-Egitim-Okullarinda-Ozel-GereksinimiOlan-Ogrenciler-ve-Ozel-Egitim-kitabi.aspx

Baglama, B. (2017). Depression as an outcome or cause of sexual dysfunctions: A review study. Global Journal of Psychology Research: New Trends and Issues, 7(3), 117-124. https://doi. org/10.18844/gjpr.v7i3.2857

Baglama, B., Demirok, M. S., \& Serttas, Z. (2017). Examining the relationship between pre-service teachers' perceptions on individual differences and attitudes towards individuals with special needs. Journal of Educational Sciences \& Psychology, 7(2). http://jesp.upg-ploiesti. ro/index.php?option=com_phocadownload\& view $=$ category $\& i d=27$ :journal-vol-vii-lxixno-22017\&Itemid $=16$

Bakker, M., van den Heuvel-Panhuizen, M., \& Robitzsch, A. (2016). Effects of mathematics computer games on special education students' multiplicative reasoning ability. British Journal of Educational Technology, 47(4), 633-648. https:// doi.org/10.1111/bjet.12249

Ball, S. J. (2012). Politics and policy making in education: explorations in sociology. London, UK: Routledge. https://www.taylorfrancis.com/ 
books/9780203808726

Barton, E. E., Reichow, B., Schnitz, A., Smith, I. C., \& Sherlock, D. (2015). A systematic review of sensory-based treatments for children with disabilities. Research in Developmental Disabilities, 37, 64-80. https://doi.org/10.1016/j. ridd.2014.11.006

Bateman, D. F., \& Bateman, C. F. (2014). A principal's guide to special education. Council for Exceptional Children. https://files.eric.ed.gov/fulltext/ ED455624.pdf

Bechtolt, S., McLaughlin, T. F., Derby, K. M., \& Blecher, J. (2014). The effects of direct instruction flashcards and a model, lead, test procedure on letter recognition for three preschool students with developmental disabilities. Journal on Developmental Disabilities, 20(1), 5. https:// oadd.org/wp-content/uploads/2014/01/41017 JoDD 20-1 v11f 5-15 Bechtolt et al.pdf

Bloh, C., Scagliotti, C., $\bar{B}$ augh, S., Sheenañ, M., Silas, S., \& Zulli, N. (2017). Using Errorless Teaching to Teach Generalized Manding for Information Using "How?". The Journal of Special Education Apprenticeship, 6(1), 4. https://scholarworks.lib.csusb.edu/josea/vol6/iss $1 / 4$

Braga-Kenyon, P., Guilhardi, P., Lionello-Denolf, K. M., \& Dube, W. V. (2017). Teaching visual conditional discriminations using errorless learning: The role of prompts requiring simple and conditional discriminative control. European Journal of Behavior Analysis, 18(2), 180-194. https:// doi.org/10.1080/15021149.2017.1309624

Cook, R. E., Klein, M. D., \& Chen, D. (2015). Adapting early childhood curricula for children with special needs. Pearson. https://scholarcommons. scu.edu/faculty books/9/

Crystal, D. (2012). English as a global language. Cambridge university press. https://books. google.rs/books?hl=en\&lr=\&id=ecsLAQAA QBAJ\&oi=fnd\&pg=PR7\&dq=Crystal, + D.+ (2012).+English + as + a + global + language. $+\mathrm{N}$ ew + York, + NY:+Cambridge+University + Pr ess.\&ots $=\mathrm{q} 4 \mathrm{~d}$ GoYVjJ\&sig=J1uh6zQwr6 c j Q k n W l v f j e O v l v M \& r e d i r $\mathrm{esc}=\mathrm{y} \# \mathrm{v}=$ onepage \&q\& $\mathrm{f}=$ false

Deepaen, W. (2016). Research and Development of the ASEAN Cartoon Lesson using the Communicative Language Teaching Approach and the Common European Framework of Reference for Languages. Global Journal of Foreign Language Teaching, 6(2), 104-110. https://doi. org/10.18844/gjflt.v6i2.715

Demirok, M. S., Baglama, B., \& Besgul, M. (2015). A content analysis of the studies in special education area. Procedia-Social and Behavioral Sciences, 197, 2459-2467. https://doi.org/10.1016/j. sbspro.2015.07.311

Demirok, M., Meral Karabacak, S., \& Aysever, H. (2019). Fait tendencies regarding disability problems within the families. Cypriot Journal of Educational Sciences, 14(2), 303-312. https:// doi.org/10.18844/cjes.v14i2.3899

Diken, I. H. (2015). Erken cocukluk doneminde dogal ortamlarda ogretim. Ankara, Turkey: Egiten Kitap. https://www.pegem.net/kitabevi/186868Erken-Cocukluk-Doneminde-Dogal-Ortamlarda-Ogretim-kitabi.aspx

Dogan, A., \& Bengisoy, A. (2017). The Opinions of Teachers Working at Special Education Centers on Inclusive/Integration Education. Cypriot
Journal of Educational Sciences, 12(3), 121132. https://doi.org/10.18844/cjes.v12i3.2440

Eratay, E., \& Yeseriroglu, E. (2017). Effectiveness of individualized teaching materials on bricklaying skills prepared with direct teaching method. New Trends and Issues Proceedings on Humanities And Social Sciences, 4(1), 304-316. https:// doi.org/10.18844/prosoc.v4i1.2270

Flanagan, R. (1995). A review of the Behavior Assessment System for Children (BASC): Assessment consistent with the requirements of the Individuals with Disabilities Education Act (IDEA). Journal of School Psychology, 33(2), 177-186. https://doi.org/10.1016/0022-4405(95)00003-5

Friend, M., \& Bursuck, M. D. (2018). Including Students with Special Needs: A Practical Guide for Classroom Teachers: $8^{\text {th }}$ Edition. Pearson Education Limited. https://www.amazon.com/ Including-Students-Special-Needs-Practical/ $\mathrm{dp} / 0134754093$

Fulcher, G. (2015). Disabling policies? A comparative approach toeducation policyand disability. Routledge. https://doi.org/10.4324/9781315668253

Gedrimas, K. (2015). Content Analysis of Qualitative Research 2011-2014 on Clients Affected by Autism Spectrum Disorder: Implications for Occupational Therapy Practice, University of Puget Sound Unpublished Master Thesis, 19.8.2019. Retrieved from; https://soundideas.pugetsound.edu/cgi/viewcontent. cgi? article $=1111 \&$ context $=\mathrm{ms}$ occ therapy

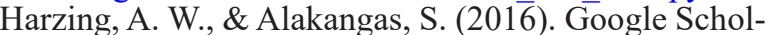
ar, Scopus and the Web of Science: a longitudinal and cross-disciplinary comparison. Scientometrics, 106(2), 787-804. https://doi.org/10.1007/ s11192-015-1798-9

Kukey, E., Gunes, H., \& Genc, Z. (2019). Experiences of Classroom Teachers on the Use of HandsOn Material and Educational Software in Math Education. World Journal on Educational Technology: Current Issues, 11(1), 74-86. https://doi. org/10.18844/wjet.v11i1.4010

Kurt, F., \& Yavuz, F. (2018). An adaptation of traditional Turkish educational games to the teaching of vocabulary in EFL environment. International Journal of New Trends in Social Sciences, 2(2), 25-31. https://doi.org/10.18844/ijntss.v2i2.3952

Lynch, K., \& Baker, J. (2005). Equality in education: An equality of condition perspective. Theory and Research in Education, 3(2), 131-164. https://doi.org/10.1177/1477878505053298

Mitchell, D. (2014). Inclusive education is a multifaceted concept. CEPS Journal, 5(1), p.9-30, 19.8.2019. Retrieved from; https://www.pedocs. de/volltexte/2015/10611/pdf/cepsj 20151 Mitchell Inclusive Education.pdf

Moed, H. F. (200̄6). Citation analysis in research evaluation (Vol. 9). Springer Science \& Business Media. https://books.google.rs/books?hl=en \&lr $=\&$ $\mathrm{id}=\mathrm{D} 9$ SaJ6awy4gC\&oi=fnd\&pg $=$ PR9\&dq $=\mathrm{M}$ oed, + H. + F. $+(2006) .+$ Citation + analysis + in + res earch + evaluation. + Springer + Science $+\% 26+\mathrm{Bu}$ siness + Media.\&ots $=$ FHn_KsZPkV\&sig=yr-LaO 4 Y Tg DmFliv0e ÜpSkrzw \& redir esc $=\mathrm{y} \# \mathrm{v}=$ onepage $\& \mathrm{q}=$ Moed $\% 2 \mathrm{C} \% 20 \mathrm{H} . \% 20$ F.\%20(2006).\%20Citation $\% 20$ analysis $\% 20$ in $\% 20$ research $\% 20$ evaluation. $\% 20$ Springer $\% 20$ Science $\% 20 \% 26 \% 20$ Business $\% 20 \mathrm{Me}$ dia. $\& \mathrm{f}=$ false

Odom, S. L., Brantlinger, E., Gersten, R., Horner, R. 
H., Thompson, B., \& Harris, K. R. (2005). Research in special education: Scientific methods and evidence-based practices. Exceptional children, 71(2), 137-148. https://doi. org/10.1177/001440290507100201

Ozdamli, F. (2017). Attitudes and Opinions of Special Education Candidate Teachers Regarding Digital Technology. World Journal on Educational Technology: Current Issues, 9(4), 191-200. https://doi.org/10.18844/wjet.v9i4.2581

Ozbal, A., \& Eski, T. (2019). Students' and teachers'opinions about ski lessons taught by using peer teaching model. Cypriot Journal of Educational Sciences, 14(2), 171-177. https:// doi.org/10.18844/cjes.v14i2.4136

Ozkan, T. \& Uzunboylu, H. (2017). Review of Scopus databases published documents related to school administrators' technology leadership strategies: a content analysis. Ponte, 73(9), 124-141. https://doi.org/10.21506/j.ponte.2017.9.40

Rajendran, V., Venkatagari, S., \& Manchireddy, S. (2017). Teaching and Learning Methodologies for Improving Students' Performance in Academics. International Journal of Learning and Teaching, 9(4), 437-444. https://doi. org/10.18844/ijlt.v9i4.1843

Sivrikaya, T., \& Y1kmış, A. (2016). Özel eğitim sınıflarında görev yapan özel eğitim mezunu olan ve olmayan öğretmenlerin öğretim süreciyle ilgili gereksinimleri [The instructional process requirements of special education graduate and non-graduate teachers working in special education classes]. Abant Izzet Baysal Üniversitesi Eğitim Fakültesi Dergisi, 16(4), 1984 2001. https://dergipark.org.tr/download/articlefile/291954

Sorakin, Y., \& Uzunboylu, H. (2017). Evaluation of content analysis of filial therapy studies. Ponte, 73(6), 334-344. https://doi.org/10.21506/j.ponte. 2017.6 .28

Sue Englert, C., Tarrant, K. L., \& Mariage, T. V. (1992). Defining and redefining instructional practice in special education: Perspectives on good teaching. Teacher education and special education, 15(2), 62-86. https://doi. org/10.1177/088840649201500203

Tavşancil, E., \& Aslan, E. (2001). Içerik analizi ve uygulama örnekleri [Content Analysis and Application Examples]. Istanbul. TR: Epsilon Yayinlari. http://www.epsilonyayinevi.com/ kitap/icerik-analizi-ve-uygulama-ornekleri.html

Tekin-Iftar, E. \& Kircaali-Iftar, G. (2013). Ozel egitimde yanlissiz ogretim yontemleri [Errorless teaching procedures in special education] (2nd ed.). Ankara, Turkey: Pegem Yayin Evi, https:// www.pegem.net/kitabevi/207443-Ozel-Egitimde-Yanlissiz-Ogretim-Yontemleri-kitabi.aspx

Uzunboylu, H., Kınık, E., \& Kanbul, S. (2017). An Analysis of Countries which have Integrated Coding into their Curricula and the Content Analysis of Academic Studies on Coding Training in Turkey. TEM Journal, 6(4), 783. https:// doi.org/10.18421/TEM64-18

Wolery, M., Bailey, D. B., \& Sugai, G. M. (1988). Effective teaching: Principles and procedures of applied behavior analysis with exceptional students (No. Sirsi) i9780205113088). http://www. sidalc.net/cgi-bin/wxis.exe/?IsisScript=SUV.xis $\&$ method $=$ post $\&$ formato $=2 \&$ cantidad $=1 \& \operatorname{expr}$ esion $=\mathrm{mfn}=013732$ 